\title{
Lingual Thyroid
}

\author{
Col SS Anand", Dr. Vikas Sood ${ }^{+}$, Lt Col PG Kumar", Air Cmde KM Suryanarayna ${ }^{* *}$, \\ Lt Col Narender Kotwal ${ }^{++}$
}

MJAFI 2006; 62 : 184-185

Key Words : Lingual thyroid

\section{Introduction}

$\mathrm{L}$ ingual thyroid is a rare anomaly with a reported incidence of 1 in 3000 of the thyroid cases seen with overall prevalence of 1 in 100,000. Of all ectopic thyroids $90 \%$ are found to be lingual thyroids. Other sites of local thyroid deposition include the cervical lymph nodes, sub mandibular glands and the trachea. Approximately two thirds of the patients with lingual thyroid lack thyroid tissue in neck [1]. Lingual thyroid is four times more common in females than in males [2]. The diagnosis of lingual thyroid is usually made clinically and radionuclide scanning is used to confirm the diagnosis. In this case report we wish to highlight the presentation, diagnosis and management of this condition.

\section{Case Report}

A four year old female child presented with history of decreased appetite, constipation and protuberance of abdomen. There was no history of delayed milestones or mental retardation. No history of dysphagia or dyspnoea. She weighed $14 \mathrm{kgs}$ and her height was $97 \mathrm{cms}$. Physical examination revealed a small midline mass at the base of the tongue (Fig 1). USS(Ultrasonography scan) abdomen was normal. Her USS neck revealed non-visualisation of thyroid in its normal anatomic location. TSH (Thyroid Stimulating Hormone ) levels were elevated at $68.20 \mathrm{uIU} / \mathrm{ml}$ (Reference range- 0.49 to $4.67 \mathrm{uIU} / \mathrm{ml})$. $\mathrm{FT}_{4}$ (Free Thyroxine ${ }_{4}$ ) was borderline low at $0.9 \mathrm{ng} / \mathrm{dl}$ (Reference range- 0.89 to $1.78 \mathrm{ng} /$ dl). Other biochemical parameters were non-contributory. A radionuclide scan was carried out using $37 \mathrm{MBq}$ of $99 \mathrm{~m} \mathrm{Tc}$ pertechnetate intravenously. Radionuclide markers were placed on the glabella and suprasternal notch to delineate the anatomic location of the ectopic thyroid. Anterior and right lateral static views of the head and neck region were obtained after 20 minutes of intravenous injection (Figs. 2 and 3). Tracer accumulation was seen in the lingual region in midline confirming the presence of lingual thyroid. There was no activity present in the thyroid bed. She was diagnosed as a case of Lingual thyroid with hypothyroidism and placed on L-Thyroxine 25ugOD. Patient was advised reevaluation after 2 months to titrate the L-thyroxine dosage.

\section{Discussion}

Lingual thyroid is defined as the presence of thyroid tissue in the midline at the base of the tongue anywhere between the circumvallate papllae and the epiglottis. The condition arises from the embryonic failure of normal thyroid tissue to descend from the foramen cecum area of the tongue base through the lower neck, presenting as a lobular midline mass in the mucosal surface of the tongue base [3]. Larger lesions can interfere with swallowing and breathing, but most patients are unaware of the mass at the time of diagnosis. The ectopic thyroid secretions are not adequate to maintain a euthyroid state. Upto $70 \%$ of patients with lingual thyroid have hypothyroidism and $10 \%$ suffer from cretinism [4].

CT (Computerised Tomography) or MR (Magnetic Resonance) scans show a midline mass extending from the midline mucosal surface of the tongue base into the medial sublingual space that can resemble a thyroglossal cyst. However, nuclear scans are better to demonstrate the location of ectopic glands [5]. Radionuclide scanning is done using $99 \mathrm{~m}$ Technetium pertechnetate and lateral/ oblique views taken additionally for better localization. False positive scans can be due to physiological uptake by salivary glands and nasal mucosa whereas pathological false positive scans can be due to meningioma, dacro-cystitis, prosthetic eye, sinusitis, dental disease and sialo-adenitis [6].

Histopathology of lingual thyroid reveals a nonencapsulated collection of embryonic or mature thyroid follicles that may extend between muscle bundles [7]. Parathyroid tissue may be seen with the lingual thyroid.

Levothyroxine therapy corrects hypothyroidism and

${ }^{*}$ Senior Advisor (Nuclear Med), ${ }^{+}$Resident (Nuclear Med), ${ }^{\#}$ Classified Specialist (Med), ${ }^{++}$Classified Specialist (Med \& Endocrinology), Dept of Nuclear Medicine, AH (R\&R), Delhi Cantt. ${ }^{* *}$ Commandant, Institute of Aerospace Medicine, Bangalore.

Received : 29.07.2004; Accepted : 26.09.2005 


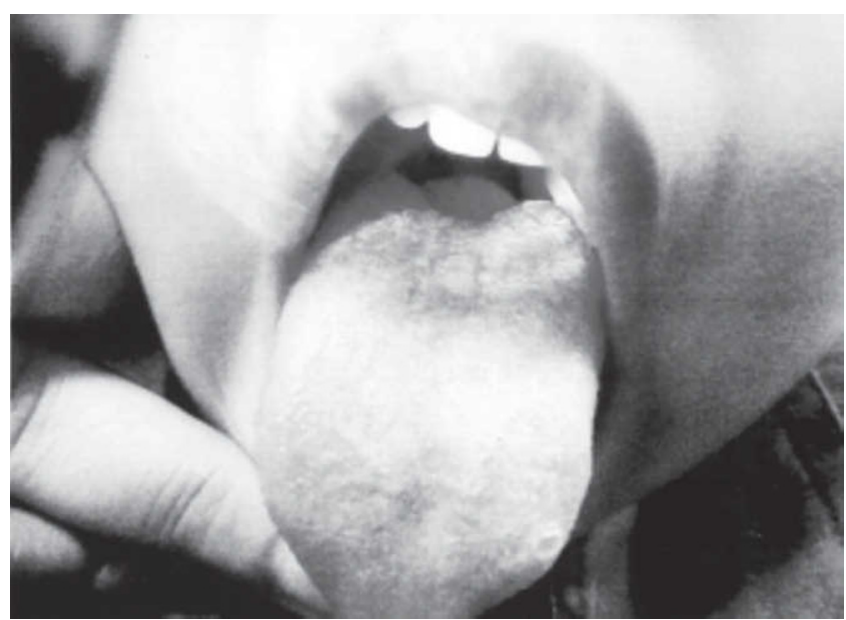

Fig. 1: Photograph showing midline mass at the base of tongue

also induces shrinkage of gland [8]. Occassionally large blood vessels are present on the surface of lingual thyroid tissue, predisposing to ulceration or hemorrhage. When symptoms of bleeding or obstruction appear, therapy by means of surgery or radioiodine ablation is warranted. Surgical excision is an effective treatment for lingual thyroid, but no treatment should be attempted until I131 radionuclide scan has determined that there is adequate thyroid tissue in the neck [8]. In patients with obstructive symptoms, Iodine-131 ablation of the ectopic thyroid tissue has proven successful and may be advantageous than surgery. In patients lacking thyroid tissue in the neck, the lingual thyroid can be excised and auto-transplanted to the muscles of the neck [9]. In our patient once the diagnosis of Lingual thyroid was established, she was put on hormone replacement therapy. She has been on regular follow up and has shown significant improvement symptomatically and some regression of the mid line mass.

\section{Conflicts of Interest}

None identified

\section{References}

1. Charles ND. Thyroid and whole-body imaging. In the thyroid, $5^{\text {th }}$ ed. Ed Ingbar and Braveman. Lippincot, Philadelphia, 1986; 458-78.

2. Arancibia P, Veliz J, Barria M, Pineda G. Lingual thyroid: report of three cases. Thyroid 1998; 8: 1055-57.

3. Williams JD, Sclafani AP, Slupchinskij O, Douge C. Evaluation and management of the lingual thyroid gland. Ann Otol Rhinol Laryngol 1996; 105: 312-16.

4. Neinas FW, Gorman CA, Devine KD, Woolner LB. Lingual thyroid. Clinical characteristics of 15 cases. Ann Intern Med. 1973; 79: 205-210.

5. Elprana D, Manni JJ, Smals AGH: Lingual thyroid.ORL J Otorhinolaryngol Relat Spec 1984; 46: 147-52.

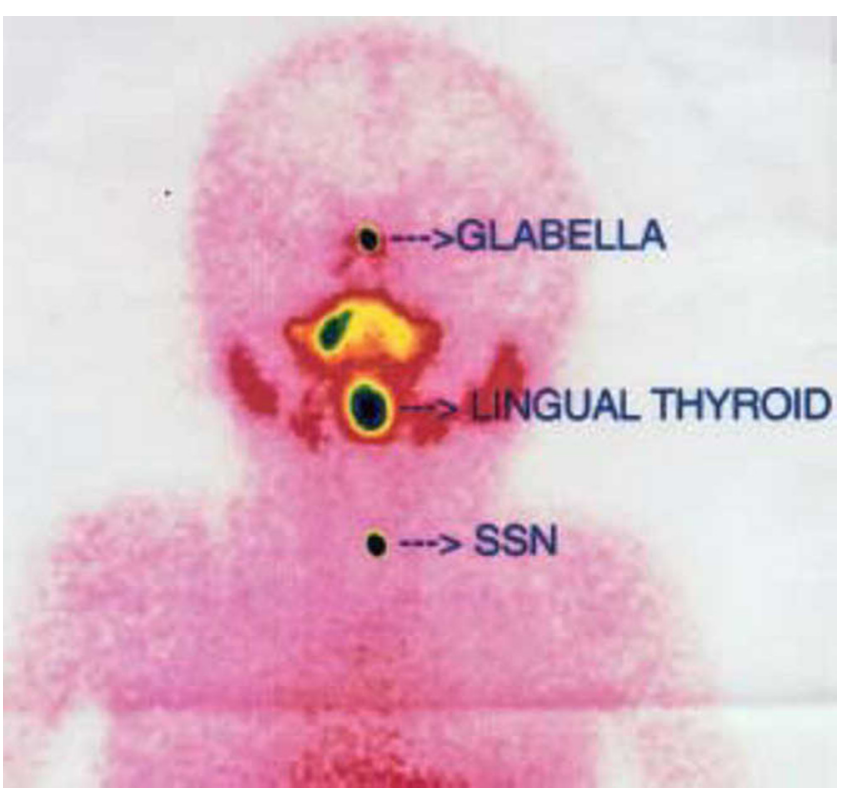

Fig. 2 : 99m Tc thyroid scan anterior view showing lingual thyroid

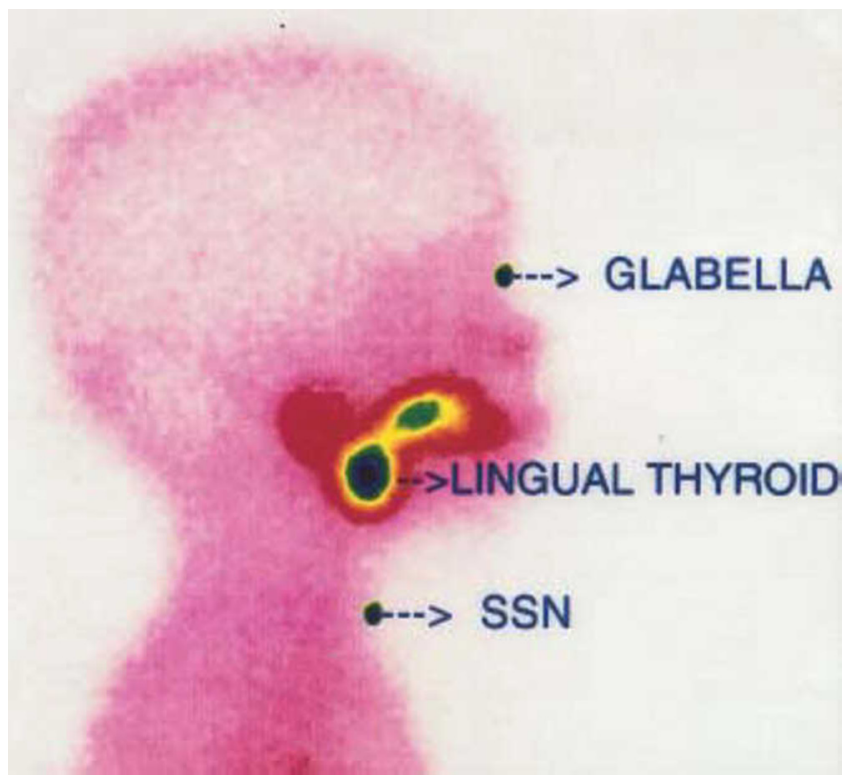

Fig. 3: 99m Tc thyroid scan lateral view showing lingual thyroid

6. Ramos-Gabatin A, Pretorius HT. Radio-nuclide turnover studies on ectopic thyroid glands-case report and survey of the literature. J Nucl Med. 1985; 26:258-62.

7. Baughman RA. Lingual thyroid and lingual thyroglossal tract remnants. A clinical and histopathologic study with review of the literature. Oral surg Oral Med Oral Pathol 1972; 34: 78199.

8. Kansal P, Sakati N. Rifai A, Woodhouse N. Lingual thyroid. Diagnosis and treatment. Arch Intern Med. 1987; 147: 204648.

9. Jones P. Auto transplantation in lingual ectopia of the thyroid gland: review of the literature and report of a successful case. Arch Dis Child. 1961; 36: 164-70. 